\title{
Reducing GHG emissions through genetic improvement for feed efficiency: effects on economically important traits and enteric methane production
}

\author{
J. A. Basarab ${ }^{1 \dagger}$, K. A. Beauchemin ${ }^{2}$, V. S. Baron ${ }^{3}$, K. H. Ominski ${ }^{4}$, L. L. Guan ${ }^{5}$, S. P. Miller ${ }^{6}$ and \\ J. J. Crowley ${ }^{5}$ \\ ${ }^{1}$ Alberta Agriculture and Rural Development, Lacombe Research Centre, 6000 C \& E Trail, Lacombe, AB, Canada T4L 1W1; ${ }^{2}$ Lethbridge Research Centre, Agriculture \\ and Agri-Food Canada, Lethbridge, AB, Canada T1J 4B1; ${ }^{3}$ Lacombe Research Centre, Agriculture and Agri-Food Canada, 6000 C \& E Trail, Lacombe, AB, Canada T4L \\ 1W1; ${ }^{4}$ Department of Animal Science, University of Manitoba, Winnipeg, MB, Canada R3T 2N2; ${ }^{5}$ Department of Agricultural, Food and Nutritional Sciences, \\ University of Alberta, Edmonton, AB, Canada T6G 2P5; ${ }^{6}$ Department of Animal and Poultry Sciences, Centre for Genetic Improvement of Livestock, University of \\ Guelph, ON, Canada N1G 2W1
}

(Received 14 January 2013; Accepted 15 April 2013)

\begin{abstract}
Genetic selection for residual feed intake (RFI) is an indirect approach for reducing enteric methane $\left(\mathrm{CH}_{4}\right)$ emissions in beef and dairy cattle. RFI is moderately heritable (0.26 to 0.43), moderately repeatable across diets ( 0.33 to 0.67 ) and independent of body size and production, and when adjusted for off-test ultrasound backfat thickness $\left(R F_{I_{\text {fat }}}\right.$ is also independent of body fatness in growing animals. It is highly dependent on accurate measurement of individual animal feed intake. Within-animal repeatability of feed intake is moderate (0.29 to 0.49) with distinctive diurnal patterns associated with cattle type, diet and genotype, necessitating the recording of feed intake for at least 35 days. In addition, direct measurement of enteric $\mathrm{CH}_{4}$ production will likely be more variable and expensive than measuring feed intake and if conducted should be expressed as $\mathrm{CH}_{4}$ production (g/animal per day) adjusted for body size, growth, body composition and dry matter intake (DMI) or as residual $\mathrm{CH}_{4}$ production. $\mathrm{A}$ further disadvantage of a direct $\mathrm{CH}_{4}$ phenotype is that the relationships of enteric $\mathrm{CH}_{4}$ production on other economically important traits are largely unknown. Selection for low $\mathrm{RF}_{\text {fat }}$ (efficient, $-R F I_{\text {fat }}$ will result in cattle that consume less dry matter (DMI) and have an improved feed conversion ratio (FCR) compared with high $R F I_{\text {fat }}$ cattle (inefficient; $+R F I_{\text {fat }}$. Few antagonistic effects have been reported for the relationships of $R F_{\text {fat }}$ on carcass and meat quality, fertility, cow lifetime productivity and adaptability to stress or extensive grazing conditions. Low $R F_{\text {fat }}$ cattle also produce $15 \%$ to $25 \%$ less enteric $\mathrm{CH}_{4}$ than $+R \mathrm{RF}_{\text {fat }}$ cattle, since $\mathrm{DMI}$ is positively related to enteric methane $\left(\mathrm{CH}_{4}\right)$ production. In addition, lower DMI and feeding duration and frequency, and a different rumen bacterial profile that improves rumen fermentation in - $\mathrm{RFI}_{\text {fat }}$ cattle may favor a $1 \%$ to $2 \%$ improvement in dry matter and CP digestibility compared with $+R \mathrm{RI}_{\text {fat }}$ cattle. Rate of genetic change using this approach is expected to improve feed efficiency and reduce enteric $\mathrm{CH}_{4}$ emissions from cattle by $0.75 \%$ to $1.0 \%$ per year at equal levels of body size, growth and body fatness compared with cattle not selected for $R F_{\text {fat }}$.
\end{abstract}

Keywords: cattle, genetic selection, methane, residual feed intake

\section{Implications}

Selection for residual feed intake $\left(-\mathrm{RFI}_{\text {fati }}\right.$ efficient) will result in cattle that consume less dry matter intake, have improved feed conversion ratio and reduced enteric $\mathrm{CH}_{4}$ emissions at equal levels of production, body size and body fatness. Rate of genetic change, using multi-trait selection and a comprehensive record keeping system, is expected to be $0.75 \%$ to

${ }^{\dagger}$ E-mail: john.basarab@gov.ab.ca
$1.0 \%$ per year compared with no selection for $\mathrm{RF}_{\mathrm{fat}}$. There will be few, if any, antagonistic effects on growth, carcass quality, fertility and cow lifetime productivity. Direct selection for an enteric $\mathrm{CH}_{4}$ phenotype must be viewed with caution since enteric methane has low to moderate repeatability ( 0.16 to 0.55 ) with distinctive diurnal patterns associated with cattle type, diet and genotype, necessitating whole day measurement for at least 35 days. Furthermore, the relationships of enteric $\mathrm{CH}_{4}$ production with other economically important traits are largely unknown. 


\section{Introduction}

Methane $\left(\mathrm{CH}_{4}\right)$ is the major greenhouse gas (GHG) emitted from ruminant production systems with $\mathrm{CH}_{4}$ from enteric fermentation accounting for $12 \%$ to $17 \%$ of GHG emissions (Beauchemin et al., 2009). In North America, the cow herd is responsible for about $85 \%$ of GHG emissions, where 6 to 7 month old weaned calves are adjusted to a high grain diet over 1 to 1.5 months, fed for 6 months and then harvested at 14 to 16 months of age (Beauchemin et al., 2010; Basarab et al., 2012a). In a calf-to-beef system that couples backgrounding and finishing, more $\mathrm{CH}_{4}$ is emitted from the forage-fed backgrounded phase than from the grain-based finishing phase and the cow herd is responsible for almost $70 \%$ of GHG emissions. The high proportion of $\mathrm{CH}_{4}$ associated with the cow herd is because of the cow herd consuming a higher proportion of the feed in a calf-to-beef system, inherently low biological efficiency of the beef cow and the very high proportion of the cow herd's diet as conserved forage, pasture, range and crop residues rather than concentrates (Allen et al., 1992; Verge et al., 2008; Capper, 2011). The impact of roughage $v$. concentrate diets on increasing the $\mathrm{CH}_{4}$ emissions in ruminant systems is well known (Johnson and Johnson, 1995; Beauchemin and McGinn, 2005; Beauchemin et al., 2008). Reducing daily $\mathrm{CH}_{4}$ emissions by increasing cereal grain content in backgrounding and finishing diets and increasing the starch content of small grain and corn silages can be an effective mitigation method that fits logically into the feedlot system (Beauchemin and McGinn, 2005; Beauchemin et al., 2009).

Methane mitigation for the cow herd may be achieved by improving the digestibility of annual and perennial forages through grazing management, increasing legume composition and utilization of species containing secondary metabolites such as tannins or saponins that affect methanogenesis in the rumen (Beauchemin et al., 2008 and 2009). Use of high-sugar perennial ryegrass (Lolium multiflorum L.) cultivars and increasing alfalfa (Medicago sativa L.) and clover (Trifolium repens $\mathrm{L}$.) sward content, where practical, can help improve forage digestibility, although increasing long-term legume content of swards can prove difficult (Dewhurst et al., 2009; Clark et al., 2011) . However, many tannin containing species showing potential are weak competitors with grasses and have a narrow climatic and geographic adaptation, necessitating a long-term plant breeding process (Abberton et al., 2007) to improve agronomic traits such as winter hardiness, seedling vigor and competitive capacity. Thus, widespread renovation of grasslands to incorporate tannin and saponin-containing species to reduce $\mathrm{CH}_{4}$ production may not be practical.

Reducing cow herd $\mathrm{CH}_{4}$ emission is a necessity for improving the carbon footprint of beef production which ranges from as low as $17 \mathrm{~kg}$ carbon dioxide equivalents $\left(\mathrm{CO}_{2} \mathrm{e}\right) / \mathrm{kg}$ carcass beef for feedlot finished beef in Canada (Verge et al., 2008; Beauchemin et al., 2010; Basarab et al., 2012a) to as high as $40 \mathrm{CO}_{2} \mathrm{e} / \mathrm{kg}$ carcass beef for grassfinished beef in Brazil (Cederberg et al., 2011). Ultimately, the combined impacts of plant and livestock breeding for low $\mathrm{CH}_{4}$ emission rates may result in substantial reductions of enteric $\mathrm{CH}_{4}$. However, the most practical and rapid mitigation procedure may be to reduce the per $\operatorname{cow} \mathrm{CH}_{4}$ emission through animal breeding and genetic selection for feed efficiency as it is permanent and cumulative (Alford et al., 2006). It is also easier to improve efficiency within the cattle population as opposed to the riskier re-establishment or renovation of long-term grasslands, much of which exists on marginal and often arid lands. Furthermore, as the global population surpasses nine billion by 2050 , improving feed efficiency becomes even more urgent to meet the increasing demand for feed grains for food and ethanol production (FAO, 2009). Moreover, feeding more grain to the cow herd is not a sustainable practice and feeding additives and supplements on pasture is not practical.

Thus, the purpose of this paper is to discuss genetic selection for feed efficiency, specifically $\mathrm{RFI}$, as an indirect approach to reducing $\mathrm{CH}_{4}$ emissions in ruminants. The impact of RFI on economically important traits will be discussed, as well as the impact of within- and between-animal variation in feed intake on $\mathrm{CH}_{4}$ emissions.

\section{Feed efficiency and RFI}

Feed is the largest variable cost and an important determinant of profitability in beef production (ARD, 2005; Ramsey et al., 2005). In North America, $55 \%$ to $75 \%$ of the total costs of calf-to-beef production systems are associated with feed costs (NRC, 2000; ARD, 2005). The cattle herd (cows, bulls and breeding replacements) consumes $82 \%$ of the feed inputs in a calf-to-beef systems where animals are harvested at 11 to 14 months of age and $63 \%$ to $64 \%$ of the feed inputs in a calf-to-beef system where animals are harvested at 19 to 23 months of age (Basarab et al., 2012a). In Irish grass-based calf-to-weanling and calf-to-beef systems the cow herd consumes about $85 \%$ and $50 \%$ of the total feed inputs, respectively (McGee, 2009). About two-thirds of the feed energy is required for body maintenance (Ferrell and Jenkins, 1985; Montano-Bermudez et al., 1990), and considerable animal-to-animal variation, independent of body size and growth, exists in maintenance requirements of cattle (Herd and Bishop, 2000; Arthur et al., 2001a and 2001b; Basarab et al., 2003; Nkrumah et al., 2006; Crowley et al., 2010). Thus, improving feed efficiency through genetic selection holds significant opportunity for the beef industry. Traditionally, feed efficiency in beef cattle was defined as feed to gain ratio or FCR. However, genetic evaluation of ratio traits like $\mathrm{FCR}$ or methane yield $\left(\mathrm{g} \mathrm{CH}_{4} / \mathrm{kg}\right.$ dry matter intake (DMI)) are problematic in that selection response is unpredictable, usually placing higher than expected emphasis on the trait with higher genetic variance (Gunsett, 1984; Kennedy et al., 1993; van der Werf, 2004). Further, the genetic correlation between the numerator (e.g. DMI) and denominator (e.g. average daily gain (ADG)) is positive (Koots et al., 1999; Berry, 2012), and therefore, selection for improved FCR has resulted in cattle that grow faster, have increased mature size, and increased maintenance and feed requirements (Bishop et al., 1991; Archer et al., 1999; 
Herd and Bishop, 2000; Crews, 2005; Kelly et al., 2010a and 2010b). As a result, efficiency measures that remove various known energy uses from feed intake, such as BW and production, are being used within breeding programs. RFI, also referred to as net feed efficiency, was first proposed by Koch et al. (1963) and was defined as the difference between an animal's actual feed intake and its expected feed requirement for maintenance of body size and production. Low RFI in growing animals represents individuals with lower feed intake at equal body size and growth, with lower maintenance energy requirements and thus greater efficiency. More recently, RFI values have been adjusted for body fatness $\left(\mathrm{RF}_{\mathrm{fat}}\right)$, thus attempting to render RFI independent of carcass fatness in slaughter cattle and later maturity or fattening in replacement heifers and bulls (Basarab et al., 2003, 2007 and 2011; Schenkel et al., 2004; Crews, 2005). Similarly, residual gain (RG) is adjusted for body size and DMI and represents animals with superior gain at equal levels of BW and DMI, and a trait that combines both RFI and RG, referred to as residual intake and gain (RFI-RG) represents efficient, fast growing animals that consume less feed (Crowley et al., 2010; Berry and Crowley, 2012). These latter two measures of feed efficiency should also be adjusted for body composition using final off-test ultrasound backfat thickness, marbling score and/or ribeye area. These measures of feed efficiency are heritable $\left(h^{2}=0.26\right.$ to 0.43$)$ and either moderately (RFI v. RG, $r_{\mathrm{g}}=-0.46, r_{\mathrm{p}}=-0.40$ ) or highly (RG v. RFI-RG, $r_{\mathrm{g}}=-0.87, r_{\mathrm{p}}=-0.85$ ) correlated with each other (Crews, 2005; Crowley et al., 2010; Berry and Crowley, 2012). In lactating dairy cows, RFI is defined as the difference between an animal's actual feed intake and its expected feed requirement for BW, fat mobilization, as well as milk fat, protein and yield (Rius et al., 2012).

\section{Feed intake, variation and repeatability}

All direct measures of feed efficiency require accurate measurement of feed intake and energy uses such as BW, growth and body composition in young cattle (Arthur et al., 2001a and 2001b; Basarab et al., 2003, 2007 and 2011), and BW, fat mobilization and milk fat, protein and yield in lactating dairy cattle (Rius et al., 2012). Typically RFI is measured in young cattle (7 to 10 months of age; maximum age difference $=60$ days) in feedlot pens fitted with feeding stations designed to automatically monitor individual animal feed intake (e.g. GrowSafe Systems Ltd, Airdrie, Alberta, Canada) following a 21 to 28 days adjustment to their test diet (Basarab et al., 2003 and 2011). The adjustment period is followed by a 76-day test period, which has been recommended as being adequate for the determination of feed intake and growth (Wang et al., 2006). Cattle are weighed before feeding on 2 consecutive days at the start and end of the test period and at 14- to 28-day intervals. They are also measured for ultrasound backfat thickness $(\mathrm{mm})$, longissimus thoracis area $\left(\mathrm{cm}^{2}\right)$ and marbling score at the start (optional) and end of the test period.

Many factors affect the DMI of cattle such as body size, growth, body composition, gender, age, season, ambient temperature, physiological status, previous nutrition and diet (NRC, 2000). Most of these factors are either equal between

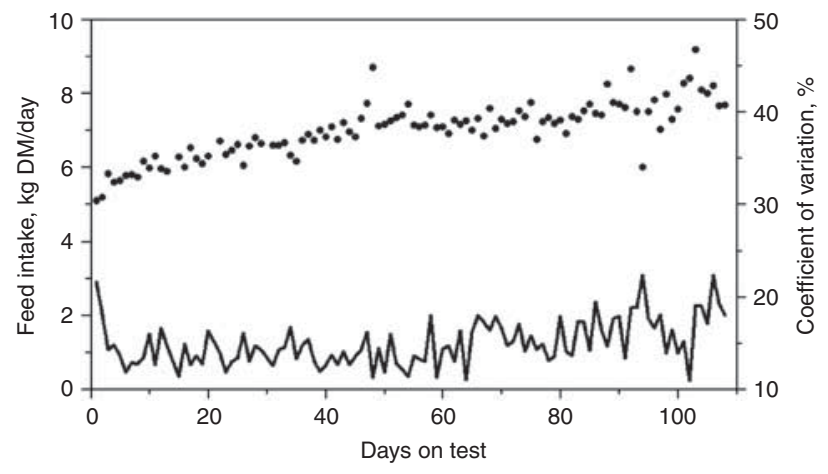

Figure 1 Daily feed intake (solid dots) and coefficient of variation (solid line) averaged for 61 beef heifers ( 8 to 12 months old) fed ad libitum a $78.2 \%$ barley silage and $21.8 \%$ barley grain diet (dry matter basis) over 108 days (Basarab, 2012, unpublished).

animals during a standardized feed intake test (e.g. gender, season, ambient temperature and physiological status) or are adjusted for, such as body size, body composition and growth. However, considerable within- and between-animal variation exists in DMI and measures of feed efficiency. The average daily feed intakes and coefficients of variation (CV) for 61 replacement heifers are presented in Figure 1 (J.A. Basarab, 2012; unpublished). The daily CV for feed intake ranged from $11 \%$ to $22 \%$ and are a reflection of the daily between-animal variation in feed intake. The betweenanimal repeatability as determined by the ratio-of variance method and conducted in 10-day intervals (e.g. 1 to 10,1 to 20,1 to 30 days) ranged from 0.325 to 0.358 for feeder heifers, 0.341 to 0.407 for feeder steers, 0.286 to 0.380 for replacement heifers, 0.374 to 0.449 for young bulls and 0.361 to 0.491 for cows (Table 1). These levels of repeatability are weak to moderate, meaning that an animal was unable to repeat its feed intake consistently over days as reflected by the deceasing repeatability estimates for the same group of cattle as the feeding interval increased (e.g. feeder steers, replacement heifers). Kelly et al. (2010b) reported a similar repeatability of 0.34 for DMI of feeder heifers weighing $418 \mathrm{~kg}$ (s.d. $=31.5 \mathrm{~kg})$ fed a total mixed ration consisting of $70: 30$ concentrate and corn silage on a dry matter (DM) basis. Wang et al. (2006) reported that the phenotypic variances for DMI decreased rapidly from 7 to 35 days of feed intake data collection and then stabilized after 35 days, indicating that extending the duration of data collection beyond 35 days resulted in only small improvement in accuracy.

The within-day pattern of feed intake for 61 replacement heifers fed ad libitum a high forage diet is illustrated in Figure 2. The animals were fed once daily at about $0930 \mathrm{~h}$. The repeatability of hourly DMI (00:00:00 to 00:59:59 $=0: 00 \mathrm{~h}$, 01:00:00 to 01:59:59 $=1: 00 \mathrm{~h}, \ldots)$ across 9 days was low for hour 0:00 to 8:00 ( $r=0.04$ to 0.13$), 10: 00$ to $18: 00(r=0.02$ to $0.16)$ and 19:00 to $23: 00$ ( $r=0.09$ to 0.28 ), and moderate for hour 09:00 ( $r=0.42)$ indicating considerable within-day within animal variation in feed intake. Thus the within-day repeatability of feed intake is affected when the animal is offered or obtains its feed and varies by RFI phenotype. Collectively, these results suggest that since enteric $\mathrm{CH}_{4}$ production is proportional 
Basarab, Beauchemin, Baron, Ominski, Guan, Miller and Crowley

Table 1 Diet ingredient composition, length of feed intake tests and repeatability of feed intake by period for various beef cattle types (Basarab, 2012, unpublished)

\begin{tabular}{|c|c|c|c|c|c|}
\hline Cattle type & Feeder steers & Feeder heifers & Replacement heifers & Young bulls & Mature cows \\
\hline Length of feed intake test & 84 & 84 & 108 & 77 & 77 \\
\hline Number of cattle & 113 & 128 & 61 & 99 & 40 \\
\hline DMI (kg) DM/day (s.d.) & $9.71(0.72)$ & $9.28(0.79)$ & $7.03(0.76)$ & $9.05(0.93)$ & $14.38(1.31)$ \\
\hline Coefficient of variation, (\%) (s.d.) & $19.3(3.0)$ & $19.2(3.3)$ & $15.1(2.5)$ & $16.4(1.9)$ & $20.9(4.6)$ \\
\hline \multicolumn{6}{|c|}{ Diet ingredient composition, \% (DM basis) } \\
\hline Barley silage & 20.0 & 20.0 & 78.2 & 72.1 & 0.0 \\
\hline Grass-alfalfa hay & 0.0 & 0.0 & 0.0 & 0.0 & 75.0 \\
\hline Straw & 0.0 & 0.0 & 0.0 & 0.0 & 25.0 \\
\hline Barley grain & 56.6 & 56.6 & 21.8 & 24.6 & 0.0 \\
\hline Corn DDGs ${ }^{1}$ & 20.0 & 20.0 & 0.0 & 0.0 & 0.0 \\
\hline Protein/trace mineral suppl. & 3.4 & 3.4 & 0.0 & 3.3 & 0.0 \\
\hline \multicolumn{6}{|c|}{ Repeatability of feed intake by periods } \\
\hline 1 to 10 days & 0.407 & 0.325 & 0.380 & 0.449 & 0.361 \\
\hline 1 to 20 days & 0.365 & 0.332 & 0.371 & 0.374 & 0.421 \\
\hline 1 to 30 days & 0.375 & 0.355 & 0.371 & 0.380 & 0.397 \\
\hline 1 to 40 days & 0.381 & 0.357 & 0.370 & 0.400 & 0.425 \\
\hline 1 to 50 days & 0.381 & 0.358 & 0.345 & 0.414 & 0.445 \\
\hline 1 to 60 days & 0.368 & 0.350 & 0.327 & 0.416 & 0.461 \\
\hline 1 to 70 days & 0.345 & 0.330 & 0.302 & 0.409 & 0.479 \\
\hline 1 to 80 days $^{2}$ & 0.341 & 0.326 & 0.305 & 0.386 & 0.491 \\
\hline 1 to 90 days & - & - & 0.301 & - & - \\
\hline 1 to 100 days & - & - & 0.292 & - & - \\
\hline 1 to 108 days & - & - & 0.286 & - & - \\
\hline
\end{tabular}

$\mathrm{DMI}=$ dry matter intake; $\mathrm{DM}=$ dry matter.

${ }^{1}$ Corn-based dried distillers grains and solubles.

${ }^{2}$ Feed intake period length was 1 to 84 days for feeder steers and heifers and 1 to 77 days for young bulls and mature cows.

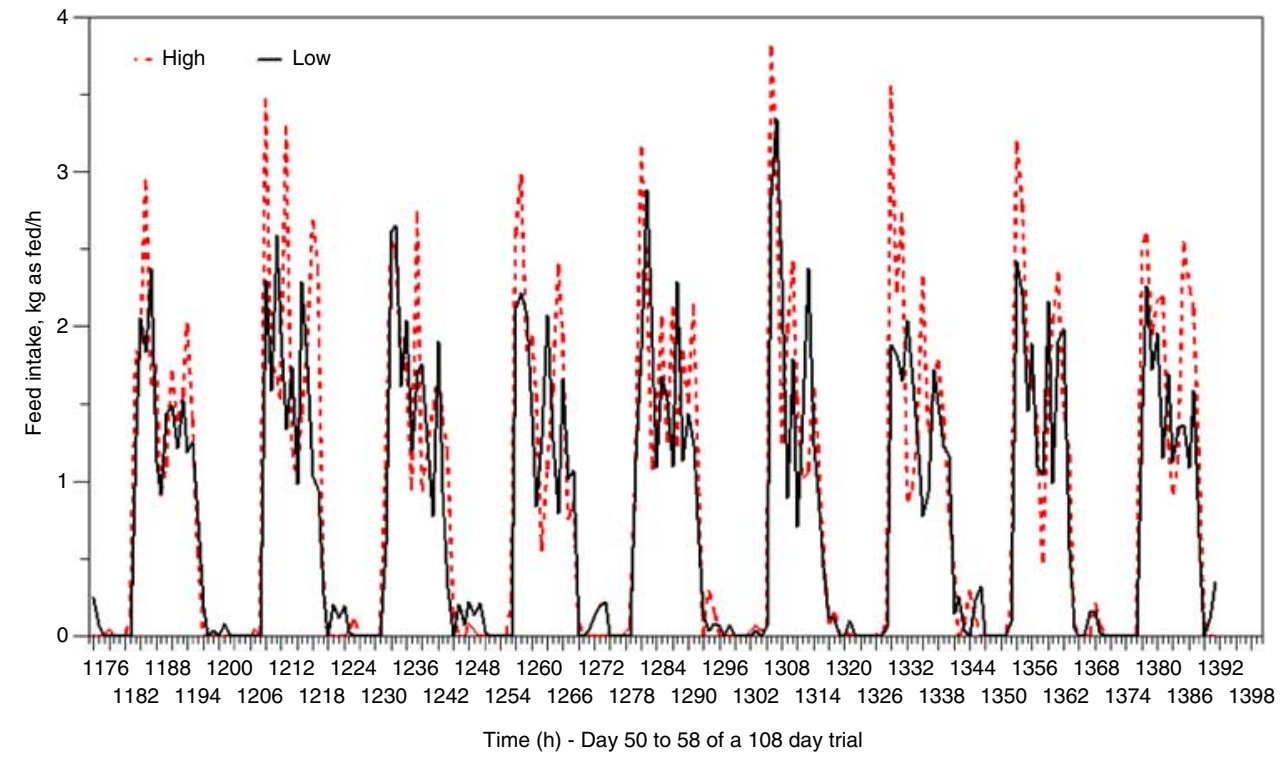

Figure 2 Daily feed intake pattern of the 10 highest and 10 lowest heifers for residual feed intake $\left(\mathrm{RF}_{\mathrm{fat}} ; 78.2 \%\right.$ barley silage and $21.8 \%$ barley grain diet, ad libitum, dry matter basis; Basarab, 2012, unpublished).

to DMI (Grainger et al., 2007), within- and between-day enteric $\mathrm{CH}_{4}$ emissions would be at least as variable as daily DMI and would require at least 35 continuous days of recording for a given diet and animal type (e.g. feeder steers on a finishing diet, replacement heifers on a growing diet).

\section{Repeatability of RFI across diets}

Because RFI is a relatively new trait, there are questions regarding its repeatability at different stages of an animal's life, on different diets and in different environments. Moderate-to-high positive phenotypic $\left(r_{\mathrm{p}}\right)$ and genetic $\left(r_{\mathrm{g}}\right)$ 
correlations, and repeatability $(r)$ have been reported between RFI measured on a grower diet and then again on a finisher diet $\left(r_{\mathrm{g}}=0.55\right.$, Crews et al., 2003; $r_{\mathrm{p}}=0.67$, Carstens and Tedeschi, 2006; $r=0.62$, Kelly et al., 2010b), and between post-weaning RFI in heifers and when measured again later in life as mature cows $\left(r_{\mathrm{g}}=0.98\right.$; Archer et al., 2002). Lower repeatability estimates $\left(r_{\mathrm{p}}=0.33\right.$ to 0.42 ) have been reported by Durunna et al. (2011) when RFI was measured between two successive feed intake test periods varying in dietary energy content (low $v$. high energy) and ambient temperature. In their study, $51 \%$ to $58 \%$ of the animals re-ranked by 0.5 s.d. ( $0.295 \mathrm{~kg} \mathrm{DM} /$ day) from the grower phase to the finisher phase which is similar to the $54 \%$ identified by Kelly et al. (2010b). This level of re-ranking for RFI, DMI and ADG occurred whether the diet changed from a grower to finisher diet or stayed the same from feeding period 1 to 2. Durunna et al. (2011) proposed that such re-ranking was because of 1 . BW and feed intake measurement error, 2. animal variation in response to compensatory gain, 3 . animal variation in efficiency with animal maturity and 4 . animal variation in diet digestibility because of differences in feeding behavior, rate of passage and rumen microbial population. Preliminary data from the Lacombe Research Centre, Canada, also confirms the moderate to strong repeatability of RFI over different stages of the animal's life (Basarab, 2012; unpublished). Replacement heifers identified as $-\mathrm{RF}_{\mathrm{fat}}$ and $+\mathrm{RFI}_{\mathrm{fat}}$ when they were 8 to 12 months of age and fed a $90 \%: 10 \%$ barley silage and barley grain diet (as fed; -0.373 v. $0.365 \mathrm{~kg}$ DM/day) were also $-\mathrm{RFI}_{\text {fat }}$ and $+\mathrm{RFI}_{\mathrm{fat}}$ when measured again as 4 to 7 year old cows and fed a 70\%:30\% grass hay and barley straw cube diet (as fed; -0.375 v. $0.459 \mathrm{~kg} \mathrm{DM} /$ day). Thus, these results indicate that $\mathrm{RFI}$, and presumably $\mathrm{RG}$ and $\mathrm{RFI}-\mathrm{RG}$, are consistent across different stages of an animal's life.

\section{RFI and related traits}

Growth, carcass traits, FCR and feed intake. There are numerous studies examining the relationships of RFI with growth and carcass traits in cattle (Arthur et al., 2001a and 2001b; Richardson et al., 2001; Herd et al., 2002; Basarab et al., 2003; Nkrumah et al., 2007; Crowley et al., 2010 and 2011) including a recent review by Hill and Ahola (2012). Briefly, RFI is not related to pre- and post-weaning growth, body size and slaughter weight in beef cattle and the phenotypic and genetic correlations are near zero. Carcass traits are also poorly correlated to RFI (Hill and Ahola, 2012), though some studies have reported a low-to-moderate correlation between RFI and carcass fatness $\left(r_{\mathrm{p}}=0.25\right.$ for grade fat; $r_{\mathrm{p}}=-0.22$ for lean meat yield; Nkrumah et al., 2004) and RFI and marbling $\left(r_{\mathrm{g}}=0.17\right.$; Robinson et al., 2001). However, when RFI is adjusted for body fatness using ultrasound backfat thickness $\left(\mathrm{RFI}_{\mathrm{fat}}\right)$, the correlations were near zero (Basarab et al., 2003 and 2007). Thus, selection for low $\mathrm{RFI}_{\text {fat }}$ breeding stock will have little to no effect on progeny growth, frame size, mature size or carcass characteristics.

RFI is moderately to highly correlated with feed intake $\left(r_{\mathrm{p}}=0.47\right.$ to $0.72 ; r_{\mathrm{g}}=0.69$ to 0.79 ; Arthur et al., 2001a and

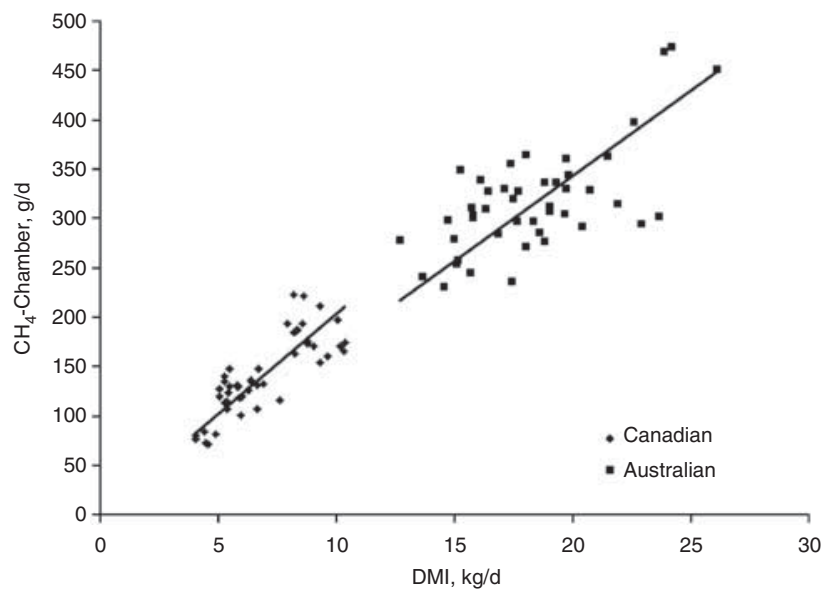

Figure 3 Relationship between $\mathrm{CH}_{4}$ emission determined in chambers and dry matter intake (DMI) for Australian and Canadian data. Lines are through the origin and have slope estimates of 17.06 for the Australian data $\left(r^{2}=0.454, P<0.0001\right)$ and 20.79 for the Canadian data $\left(r^{2}=0.677, P<0.0001\right)$. Adapted from Grainger et al. (2007).

2001b; Herd et al., 2002; Basarab et al., 2003; Nkrumah et al., 2007; Kelly et al., 2010b) and FCR ( $r_{\mathrm{p}}=0.46$ to 0.70; $r_{\mathrm{g}}=0.66$ to 0.88; Arthur et al., 2001a and 2001b; Basarab et al., 2003; Kelly et al., 2010b). This implies that selection for $-\mathrm{RFI}_{\mathrm{fat}}$ will decrease feed intake at equal levels of BW, growth and body fatness, and will improve feed-to-gain ratio in feeder cattle and growing replacement heifers. These results also imply that selection for $-\mathrm{RFI}_{\text {fat }}$ will decrease $\mathrm{CH}_{4}$ emissions (g/animal per day) since $\mathrm{CH}_{4}$ emissions are proportional to feed intake (Blaxter and Clapperton, 1965; Beauchemin and McGinn, 2006; IPCC, 2006). A comprehensive analysis of Australian and Canadian data spanning a wider range in enteric $\mathrm{CH}_{4}$ emissions, diet quality, animal type (lactating dairy cows; growing beef steers) and $\mathrm{CH}_{4}$ measurement technique $\left(\mathrm{SF}_{6}\right.$ in whole animal chambers; whole animal chambers) revealed strong positive, linear relationships between $\mathrm{CH}_{4}$ emissions (g/day) and DMI (Australian, $R^{2}=0.45, P<0.001$; Canadian, $R^{2}=0.68$, $P<0.001$; Grainger et al., 2007; Figure 3). Generally, the higher the DMI the higher the daily enteric $\mathrm{CH}_{4}$ emissions as more substrate is available for rumen fermentation and more hydrogen is available for methanogenesis (Pinares-Patinõ et al., 2003; Lovett et al., 2005; Beauchemin and McGinn, 2006; Grainger et al., 2007).

Since $\mathrm{CH}_{4}$ production rates (g/day) are proportional to $\mathrm{DMI}$, they are often standardized to $\mathrm{g} \mathrm{CH}_{4} / \mathrm{kg} \mathrm{DMI}$ or expressed as a percentage of gross energy intake (GEI). Unfortunately, this has resulted in contradictory conclusions as $\mathrm{CH}_{4}$ production expressed as $\mathrm{g} / \mathrm{kg} \mathrm{DMI}$ or as a percent of GEl are not related to DMI $(r<0.20, P>0.20$; Beauchemin and McGinn, 2006). In addition, when feed intake was expressed relative to maintenance, thus removing some variation because of daily feed intake, it was moderately and negatively associated with $\mathrm{CH}_{4}$ expressed as percent of $\mathrm{GEI}$ $(r=-0.30 ; P=0.04)$. Thus, increasing the intake level to 2.5 times maintenance decreased $\mathrm{CH}_{4}$ conversion by $19 \%$, presumably because of reduced retention time in the rumen 
and lower acetate:propionate ratio (Beauchemin and McGinn, 2006). Lower acetate and greater propionate production directs hydrogen away from $\mathrm{CH}_{4}$ production. Despite the strong positive relationship between daily $\mathrm{CH}_{4}$ production and $\mathrm{DMI}$, there are numerous within- and betweenanimal factors that are unrelated to DMI since $54 \%$ to $70 \%$ of the total variation in daily $\mathrm{CH}_{4}$ production is associated with the animal despite being fed the same diet (PinaresPatinõ et al., 2003).

Feeding behavior. The genetic components of feeding behavior are important in animal breeding since they have economic and animal welfare implications, contribute to animal-to-animal variation in energetic efficiency (Herd et al., 2004; Herd and Arthur, 2009; Kelly et al., 2010a), digestibility and enteric methane emissions (Johnson et al., 1994; Harper et al., 1999). Feeding behaviors such as feeding duration, frequency and rate are moderately repeatable ( $r=0.37$ to 0.62 : Kelly et al., 2010b) and heritable $\left(h^{2}=0.28\right.$ to 0.38; Nkrumah et al., 2007). Furthermore, research from Australia (Robinson and Oddy, 2004), Canada (Basarab et al., 2007; Nkrumah et al., 2007; Montanholi et al., 2010; Durunna et al., 2011), Ireland (Kelly et al., 2010a) and the United States (Golden et al., 2008; Bingham et al., 2009) have reported mostly moderate to strong positive correlations $(r=0.08$ to 0.62$)$ of $\mathrm{RFI}$ and $\mathrm{RFI}_{\text {fat }}$ to feeding duration, frequency and eating rate. Several of these relationships are further illustrated in Figures 4 and 5 by the moderate correlation between $\mathrm{RF}_{\mathrm{fat}}$ and feeding event frequency in replacement heifers fed a growing diet $\left(r_{p}=0.16\right.$, $P<0.1)$ and cows fed straw : hay cubes $\left(r_{\mathrm{p}}=0.57, P<0.001\right)$ tested for feed efficiency at the Lacombe Research Centre, Canada (Basarab, 2012, unpublished). Collectively, these results show that $-\mathrm{RFI}_{\text {fat }}$ and $+\mathrm{RF}_{\mathrm{fat}}$ cattle have distinctive diurnal patterns of feeding behavior, with inefficient cattle having $14 \%$ to $22 \%$ more daily feeding events than efficient cattle (Nkrumah et al., 2007; Kelly et al., 2010a), thus expending 2\% to $5 \%$ more energy in feeding activities (Herd et al., 2004; Basarab et al., 2011). There are also implications for the direct measurement of enteric $\mathrm{CH}_{4}$ as $\mathrm{CH}_{4}$ emissions from the rumen are closely associated with feeding patterns; higher after feeding than at ruminating or resting (Johnson et al., 1994). Thus, whole-day measurement repeated across many days (e.g. 35 days as recommended for DMI by Wang et al., 2006) are required to accurately reflect animal-to-animal differences in enteric $\mathrm{CH}_{4}$ production.

In a recent review on feed efficiency and animal robustness, Rauw (2012) hypothesized that because efficient animals have decreased feeding event duration and frequency, they are less able to adapt to changes in environment conditions. However, observation of beef cows reared under extensive Canadian winter conditions has shown that cows that produced -RFI calves actually had higher backfat thickness with no differences in lifetime productivity compared with their herd mates that produced $+\mathrm{RFI}$ calves (Basarab et al., 2007). In addition, $-\mathrm{RF}_{\mathrm{fat}}$ heifers calving for the first time had lower calf death within 30 days of birth than $+\mathrm{RFI}_{\mathrm{fat}}$ heifers, suggesting that calves

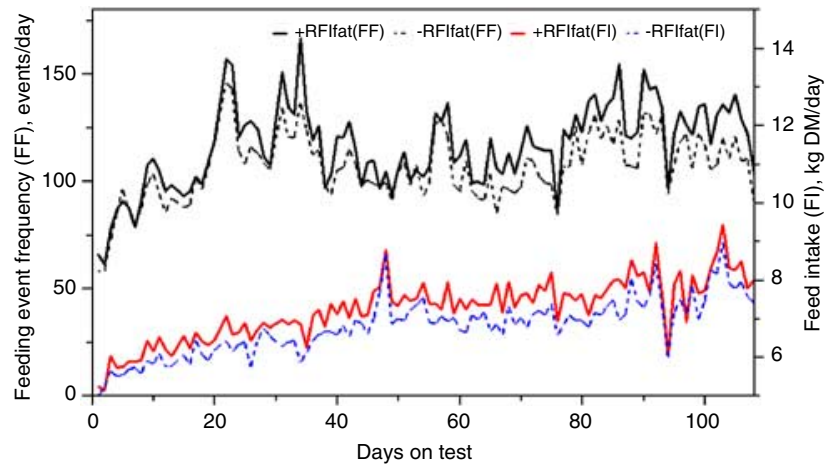

Figure 4 Daily average feeding event frequency (FF) and feed intake (FI) for residual feed intake $\left(+\mathrm{RFI}_{\text {fat }} ; n=29\right)$ and $-\mathrm{RFI}_{\text {fat }}(n=32)$ beef heifers fed ad libitum a $78.2 \%$ barley silage and $21.8 \%$ barley grain diet (dry matter (DM) basis) over 108 days. Means (s.d.) are as follows: +RFI fat, $\mathrm{FF}=116.3$ events/day (33.2), black solid line; $-\mathrm{RFI}_{\text {fat }}, \mathrm{FF}=106.3$ events/ day (33.2), black dashed line; $+\mathrm{RFI}_{\text {fat, }} \mathrm{FI}=7.27 \mathrm{~kg} \mathrm{DM} /$ day (1.34), red solid line; $-\mathrm{RFI}_{\mathrm{fat}}, \mathrm{FI}=6.81 \mathrm{~kg} \mathrm{DM} /$ day (1.25), blue dashed line (Basarab, 2012, unpublished).

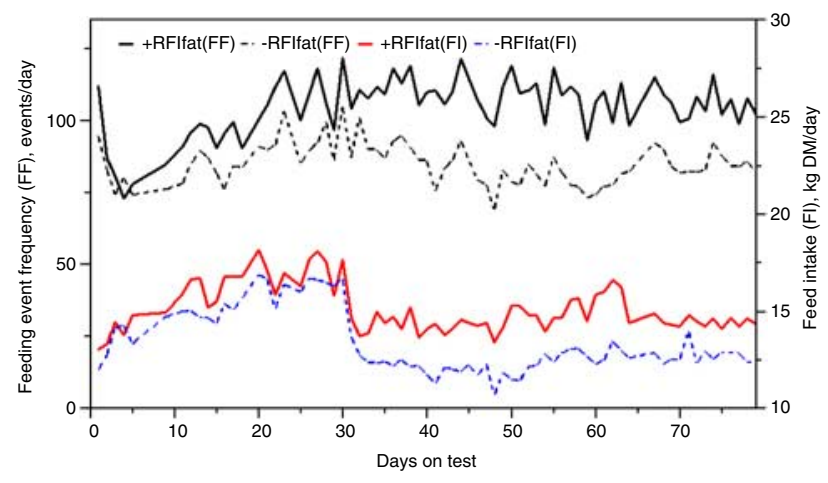

Figure 5 Daily average feeding event frequency (FF) and feed intake (FI) for residual feed intake $\left(+\mathrm{RFI}_{\text {fat }} ; n=23\right)$ and $-\mathrm{RFI}_{\text {fat }}(n=17)$ beef cows fed a hay-straw cube over 79 days (25\% straw: $75 \%$ grass hay-alfalfa mix, dry matter (DM) basis). Means (s.d.) are as follows: $+\mathrm{RFI}_{\mathrm{fat}}, \mathrm{FF}=105.3$ events/day (21.0), black solid line; $-\mathrm{RFI}_{\mathrm{fat}}, \mathrm{FF}=85.5$ events/day (17.9), black dashed line; $+\mathrm{RFI}_{\text {fat }}, \mathrm{FI}=15.10 \mathrm{~kg} \mathrm{DM} /$ day (1.55), red solid line; $-\mathrm{RFI}_{\mathrm{fat}}, \mathrm{FI}=13.32 \mathrm{~kg} \mathrm{DM} /$ day (2.42), blue dashed line. Ad libitum and about $85 \%$ restricted feeding occurred from days 1 to 30 and 31 to 79 , respectively (Basarab, 2012, unpublished).

born to efficient cows have improved early life survival possibly because of lower maintenance requirements and more available nutrients for accumulation of body fat, better uterine environment (Basarab et al., 2007 and 2011) and possibly improved calf passive immunity status. Indeed, recent unpublished research from the Lacombe Research Centre confirm these findings in that $-\mathrm{RF}_{\mathrm{fat}}$ cows gained more body fat and $\mathrm{BW}$ than $+\mathrm{RFI}_{\mathrm{fat}}$ cows when both groups swath grazed forages for the first time during Canadian winters where night time ambient temperatures dropped below $-20^{\circ} \mathrm{C}$ and animals grazed through the snow from November to March. Previous to this, both -RFI and +RFI young cows had been wintered together in smaller holding areas and fed barley silage to meet their nutritional requirements. Thus, while efficient cattle have lower feeding event duration and frequency and lower feed intake this does not mean that $-\mathrm{RF}_{\mathrm{fat}}$ animals cannot compete 
or acquire forages during extensive grazing. Instead, it may imply that efficient animals are more adaptable and less susceptible to stress than $+\mathrm{RF}_{\mathrm{fat}}$ or inefficient animals.

Fertility and cow productivity. The relationships of RFI or $\mathrm{RF}_{\text {fat }}$ on fertility and productivity in heifers and cows have recently been reviewed by Basarab et al. (2012b). Briefly, $-\mathrm{RFI}$ and +RFI cows and heifers were similar in culling, pregnancy, calving and weaning rate, calving pattern, calf birth weight, level of dystocia and kilogram of calf weaned per mating opportunity (Arthur et al., 2005; Basarab et al., 2007 and 2011), however, -RFI cows calved 5 to 6 days later in the year than $+\mathrm{RFI}$ cows suggesting a delay in the onset of first estrus that may have delayed conception during the first breeding season (Arthur et al., 2005; Basarab et al., 2007; Shaffer et al., 2011). When RFI was adjusted for body fatness (final off-test backfat thickness; $\mathrm{RFI}_{\mathrm{fat}}$ ) no differences were observed in percentage of $-\mathrm{RF}_{\mathrm{fat}}$ and $+\mathrm{RFI}_{\mathrm{fat}}$ heifers reaching puberty by $10,11,12,13,14$ or 15 months of age nor in the percentage of calves born by day 28 of the calving season (86.5 v. 92.0, $P=0.28$; Basarab et al., 2011 and 2012b). Calving difficulty, age at first calving, calf birth weight, calf pre-weaning ADG, calf actual and 200-day weaning weight and heifer productivity, expressed as $\mathrm{kg}$ calf weaned per heifer exposed to breeding, were also similar between $-\mathrm{RF}_{\mathrm{fat}}$ and $+\mathrm{RFI}_{\mathrm{fat}}$ heifers. Fertility of young bulls, as measured by scrotal circumference, breeding soundness evaluation, calves born per sire and semen characteristics, for the most part has been unrelated to RFI, though several weak associations $\left(r_{\mathrm{p}}=0.13\right.$ to $\left.0.21 ; P<0.05\right)$ have been observed with sperm morphology and motility (Hafla et al., 2012; Wang et al., 2012). These observations may also reflect the need to adjust RFI for off-test ultrasound backfat thickness and feeding behaviors in an effort to prevent the selection for later maturing bulls.

Basarab et al. (2007 and 2011) also reported a lower calf death loss in $-\mathrm{RF}_{\mathrm{fat}}$ compared with $+\mathrm{RF}_{\text {fat }}$ heifers and cows, and suggested that the improved early life survival of progeny from - RFI mothers may be because of their improved feed efficiency resulting from more available nutrients and a better uterine environment compared with + RFI mothers. In addition, mothers that produced - RFI progeny consistently had 2 to $3 \mathrm{~mm}$ more backfat thickness, on average, over the 12th and 13th ribs and lost less weight during early lactation (pre-calving to pre-breeding) than mothers that produced + RFI progeny, thus indicating that the lower maintenance requirement of $-\mathrm{RFI}$ heifers and cows results in the accumulation of body fat or the loss of less body fat and weight during stressful environmental periods.

\section{RFI, methane production and digestibility}

Reduction of $\mathrm{CH}_{4}$ emissions from ruminants is important because it represents $2 \%$ to $12 \%$ loss of feed energy by cattle (Johnson et al., 1994; Johnson and Johnson, 1995) and is linked to global warming. There are numerous opportunities for nutritional and microbial manipulation to reduce
$\mathrm{CH}_{4}$ emissions in ruminants and these have been extensively reviewed by Beauchemin et al. (2008) and McAllister and Newbold (2008). Enteric $\mathrm{CH}_{4}$ is produced during fermentation of feeds in both the reticulorumen and hindgut, with $95 \%$ to $98 \%$ excreted through the esophagus and lungs via brief 5 to $30 \mathrm{~s}$ eructations, burps and/or breaths and $2 \%$ to $5 \%$ via flatus (Johnson and Johnson, 1995; Grainger et al., 2007). This leads to large fluctuations within and between days, and from animal-to-animal in $\mathrm{CH}_{4}$ production (Beauchemin and McGinn, 2005 and 2006; Jones et al., 2011; Pinares-Patinõ et al., 2011). Methane production has low-to-moderate heritability $\left(h^{2}=0.13\right.$ to 0.38 ; Crowley et al., 2010; de Haas et al., 2011; Pinares-Patinõ et al., 2011), low-to-moderate repeatability ( $r=0.16$ to 0.55 ; Robinson et al., 2010; PinaresPatinõ et al., 2011) and is positively correlated to RFI $\left(r_{\mathrm{p}}=\right.$ 0.35 to 0.44 ; Nkrumah et al., 2006; Hegarty et al., 2007), suggesting that it may be possible to breed for lower $\mathrm{CH}_{4}$ production and/or yield $\left(\mathrm{g} \mathrm{CH}_{4} /\right.$ day; $\left.\mathrm{g} \mathrm{CH}_{4} / \mathrm{kg} \mathrm{DMI}\right)$ either by directly selecting for a lower $\mathrm{CH}_{4}$ phenotype or indirectly by selecting for low $\mathrm{RF}_{\text {fat }}$. The latter approach will be the emphasis of the following discussion.

A review of the scientific literature revealed three basic hypotheses as to why $-\mathrm{RFI}$ or $-\mathrm{RF}_{\text {fat }}$ animals have lower $\mathrm{CH}_{4}$ production and/or yield (Ørskov et al., 1988; Nkrumah et al., 2006; Hegarty et al., 2007; Pinares-Patinõ et al., 2011; Waghorn and Hegarty, 2011; Rius et al., 2012; Gomes et al., 2013). The first hypothesis is primarily feed intake driven. Efficient animals have lower feed energy intake at equal levels of production, BW and fatness and lower $\mathrm{CH}_{4}$ and manure production since $\mathrm{CH}_{4}$ production is either $6.5 \%$ or $4 \%$ of GEI $(<85 \%$ v. $\geq 85 \%$ concentrates in the diet) and manure production and $\mathrm{N}$ excretion is predicted based on $\mathrm{DMI}$, and total digestible nutrient, $\mathrm{CP}$ and ash content of the diet (Herd et al., 2002; IPCC, 2006). This hypothesis assumed no effects of RFI phenotypes on digestibility or $\mathrm{CH}_{4}$ yield ( $\mathrm{g} / \mathrm{kg} \mathrm{DMl} ; \%$ of GEI). The second hypothesis is also feed intake driven but assumed that feed intake affects retention time of digesta in the rumen and rumen volume such that longer retention times and higher rumen volumes are associated with increased $\mathrm{CH}_{4}$ production, likely because of increased digestion of structural carbohydrates and a greater supply of hydrogen for methanogens (Nkrumah et al., 2006; Hegarty et al., 2007; Gomes et al., 2013). Any small differences in DM or $\mathrm{N}$ digestibility (1 to 2 percentile points) are attributed to decreased metabolizability of the diet and increased heat increment of feeding at higher levels of feed intake above maintenance (Ferrell and Jenkins, 1985). The third hypothesis suggested that inherent differences in feeding behavior and activity as previously discussed, feed intake and ruminal retention time results in a host-mediated response in microbial communities (bacteria, archaea, ciliate protozoa and fungi) favoring improved DM and $\mathrm{N}$ digestibility (Russell and Gahr, 2000; Nkrumah et al., 2006). Higher ruminal fermentation rates favor a shift in acetate to propionate, thus decreasing the hydrogen available for methanogens.

Only a few studies have actually measured whole or near-whole day $\mathrm{CH}_{4}$ production from cattle differing in RFI. 
Measurement techniques have included indirect calorimetry where $\mathrm{CH}_{4}$ was measured continuously over 16 to 24-h periods (Nkrumah et al., 2006; Montanholi et al., 2011), SF6 as a tracer gas where $\mathrm{CH}_{4}$ was measured in a series of 10-day measurement periods (Hegarty et al., 2007), respiration chambers over $48 \mathrm{hs}$ (Waghorn and Hegarty, 2011) and open path Fourier Transform Infrared spectrophotometry over two 6-day periods (summer and winter, Western Australia; Jones et al., 2011). Diets varied from high grain fed to steers to low- and high-quality forage fed to cows. In three of these studies, -RFI steers consumed less feed and produced $24.6 \%$ to $27.5 \%$ less $\mathrm{CH}_{4}$ than $+\mathrm{RFI}$ steers (Canadian, University of Alberta data, 97.5 v. $129.3 \mathrm{~g}$ $\mathrm{CH}_{4} /$ day, $P=0.04$; Canadian, University of Guelph data, 493.4 v. $680.2 \mathrm{ml} \mathrm{CH} / \mathrm{min}, P=0.08$; Australian data, $142 \mathrm{v}$. $190 \mathrm{~g} \mathrm{CH}_{4} /$ day, $P=0.01$ ). When expressed as $\%$ of GEI or per kg DMI, only the Canadian data reported lower methane yields for $-\mathrm{RFI}$ as compared with $+\mathrm{RFI}$ steers $(3.19 \% \mathrm{~V}$. $4.28 \%$ of GEI, $P=0.04$ ). The cow results were more variable and ranged from no difference between RFI phenotypes in $\mathrm{CH}_{4}$ production (Waghorn and Hegarty, 2011) to $23.1 \%$ less $\mathrm{CH}_{4}$ produced for $-\mathrm{RFI}$ cows and their calves grazing high quality (81\% digestibility) annual pasture during the winter $\left(0.34 \pm 0.017\right.$ v. $0.46 \pm 0.023 \mathrm{~g} \mathrm{CH}_{4} / \mathrm{kg}$ live weight (LW)/day, $P<0.05 ; 13.1 \pm 1.63$ v. $14.0 \pm 1.50 \mathrm{~kg} \mathrm{DM} / 500 \mathrm{~kg} \mathrm{LW} /$ day, $P>0.1$; Jones et al., 2011). In this same study, RFI groups were similar in $\mathrm{CH}_{4}$ production when the cows were pregnant and grazing poor quality ( $55 \%$ digestibility) annual pasture during the summer $\left(0.26 \pm 0.018\right.$ v. $0.26 \pm 0.013 \mathrm{~g} \mathrm{CH}_{4} / \mathrm{kg}$ cow LW/day, $P>0.1 ; 10.2 \pm 0.27$ v. $10.7 \pm 0.26 \mathrm{~kg} \mathrm{DM} / 500 \mathrm{~kg}$ LW/day; $P>0.1$ ). The lack of differences in $\mathrm{CH}_{4}$ emissions between the RFI phenotypes during the summer may be attributed to the low CP content (7.1\%) of the poor quality forage as $8 \%$ to $9 \% \mathrm{CP}$ is required to meet the nitrogen requirements for the rumen microbes (NRC, 2000), thus affecting DMI and digestibility. The lack of difference in DMI between -RFI and +RFI cows may also be because of the large error associated with the mass balance method used to assess forage intake.

Similarly, only a few studies have measured DM and/or N digestibility in cattle differing in RFI (Nkrumah et al., 2006; Cruz et al., 2010; Lawrence et al., 2011; Rius et al., 2012). In the study by Nkrumah et al. (2006), DM and CP digestibility tended to be greater for -RFI compared with + RFI steers, with medium RFI steers being intermediate $(75.3 \%$ v. $73.4 \%$ v. $70.9 \%$ for DM digestibility, $P=0.10 ; 74.7 \%$ v. $73.5 \%$ v. $69.8 \%$ for CP digestibility, $P=0.09$ ). In addition, RFI was positively associated with $\mathrm{DMI}$, feeding event duration and bunk attendance, and feeding event duration was negatively related to DM $(r=-0.55)$ and CP $(r=-0.47)$ digestibility, indicating that lower feeding durations were associated with lower DMI and improved digestibility. These results are in agreement with Rius et al. (2012) where 16 ruminally cannulated (eight $-\mathrm{RFI}$ and eight $+\mathrm{RFI}$ ) early lactating Holstein-Friesian heifers were fed ad libitum fresh vegetative ryegrass during an 8-day digestibility trial where total intake of nutrients and outputs of milk, feces and urine were determined. Efficient (-RFI) cows had greater apparent $\mathrm{N}$ digestibility $(77.2 \%$ v. $75.5 \%, P=0.02)$ and tended to have greater DM $(78.5 \%$ v. $77.3 \%, P=0.07)$ and organic matter $(81.1 \%$ v. $80.1 \%, P=0.08)$ digestibility than +RFI cows. Gomes et al. (2013), after a 5-day adaptation period, sampled feed and orts and collected total feces and urine throughout a 48-h period on $12-\mathrm{RFI}$ and $12+\mathrm{RFI}$ steers fed a finishing diet. Non-significant numeric differences between RFI phenotypes were observed in apparent DM digestibility (-RFI, 75.2\%; $+\mathrm{RFI}, 72.3 \% ; P=0.18)$, nitrogen retention (-RFI, $60.0 \mathrm{~g} /$ day; $+\mathrm{RFI}, 53.2 \mathrm{~g} / \mathrm{day}$; $P=0.34)$ and nitrogen excretion ( $-\mathrm{RFI}, 97.3 \mathrm{~g} /$ day; $+\mathrm{RFI}$, $108.8 \mathrm{~g} / \mathrm{day} ; P=0.31)$. Cruz et al. (2010) and Lawrence et al. (2011) used internal markers (lignin and acid-insoluble ash) and fecal grab samples to estimate digestibility reported no differences in N or DM digestibility between -RFI and + RFI cattle.

Thus, there is direct evidence indicating that -RFI cattle will produce less $\mathrm{CH}_{4}\left(\mathrm{~g} \mathrm{CH}_{4} /\right.$ day) than $+\mathrm{RFI}$ cattle, primarily through lower feed intake at equal levels of production, BW and fatness. However, the evidence for greater feed efficiency in $-\mathrm{RF}_{\text {fat }}$ cattle due, at least partially to an enhanced capacity to digest feeds is controversial as $\mathrm{CH}_{4}$ yield $\left(\mathrm{g} \mathrm{CH}_{4} /\right.$ $\mathrm{kg} \mathrm{DMI}$ or as \% of GEI) between RFI phenotypes were inconsistent among studies. The relationship between RFI and $\mathrm{DM}$ and $\mathrm{N}$ digestibility is also unclear, though it is known that higher DMI will increase $\mathrm{CH}_{4}$ production, but shorter rumen retention time associated with higher DMI will lower digestibility by 1 to 4 percentage points depending on the level of feed intake above maintenance, lower $\mathrm{CH}_{4}$ yield $(\mathrm{g} / \mathrm{kg}$ DMI) and increase heat increment of feeding (Ferrell and Jenkins, 1985; NRC, 2000; Waghorn and Hegarty, 2011). Thus, the small differences in digestibility between -RFI and + RFI cattle observed in the above mentioned studies are more likely because of differences in feed intake rather than because of any real differences in ability to digest feed.

\section{$R F I$, rumen microbiota and methane emissions}

This section examines the third hypothesis which implies that inherent differences between RFI phenotypes in feed intake and feeding behaviors results in host-mediated alterations in microbial profiles and fermentation patterns. Indeed, the rumen bacterial profiles and not the total numbers of bacterial cells of $-\mathrm{RFI}$ steers are different than those in + RFI cattle when fed growing (Hernandez-Sanabria et al., 2010) and finishing diets (Guan et al., 2008; HernandezSanabria et al., 2010). A recent study by Irish researchers further confirmed segregation of rumen microbial profiles in forage-fed beef heifers with different RFI values (Carberry et al., 2012). In this study, abundance of some Prevotella species was higher $(P<0.0001)$ in $+\mathrm{RFI}$ animals. Further, some Prevotella sp. have been associated with increased butyrate production, poorer FCR and a lower straight-chain to branched-chain volatile fatty acids (VFA) ratio (HernandezSanabria et al., 2010). Conversely, other Prevotella species were higher in - RFI animals (Ghoshal et al., 2012). The Prevotella genus predominates (up to $60 \%$ of total population) in the rumen under many dietary conditions 
(Stevenson and Weimer, 2007) and plays a role in degradation and utilization of starch (Cotta, 1992) and proteins (Wallace et al., 1993). Therefore, it is not surprising that some species belonging to this genus are associated with better fermentation profiles and feed efficiency. In addition, some bacterial species such as Clostridium sp. are associated with lower straight-chain to branched-chain VFAs and improved FCR (Hernandez-Sanabria et al., 2010). Branchedchain VFAs are derived from branched-chain amino acids (e.g. leucine, valine and isoleucine) and the ratio of straightchain to branched-chain VFA is an indicator of amino acid fermentation (Hernandez-Sanabria et al., 2010). Thus, Clostridium sp. can ferment amino acid and peptide to produce ammonia (Eschenlauer et al., 2002), suggesting that the increased amino acid metabolism plays an important role in feed efficiency. Furthermore, some novel ruminal species have been observed to be associated with specific fermentation functions. Pelotomaculum thermopropionicum, for example, is an anaerobic propionate-oxidizing bacterium (Imachi et al., 2002) that has been associated with low propionate and improved FCR (Hernandez-Sanabria et al., 2010). Propionate, one of the major VFA in the rumen, is the major gluconeogenic precursor whose concentration is dependent on digestible energy intake (Stewart et al., 1997).

Recent high throughput sequencing studies have revealed that the rumen has greater than 700 bacterial species (Brulc et al., 2009), suggesting that there is limited value in studying the rumen microbial community at the taxonomy level and emphasizing the need to examine enzymes involved in carbohydrate and amino acid metabolism. Use of a metagenomic approach has revealed variation in ruminal microbial enzymes between -RFI and +RFI animals (Ghoshal et al., 2012). The activity of enzymes involved in benzoate metabolism was higher in the rumen of + RFI steers while enzymes involved in carbazol degradation were higher in - RFI steers. The 4-carboxymuconolactone decarboxylase enzyme plays a role in benzoate degradation which leads to overproduction of $\mathrm{CO}_{2}$ ultimately leading to increased production of $\mathrm{CH}_{4}$ in $+\mathrm{RFI}$ steers. Further, carbazol degradation may lead to a decreased production of $\mathrm{CO}_{2}$ which lowers the substrate necessary for $\mathrm{CH}_{4}$ emission.

The methanogenic process plays a role in regulating the overall fermentation in the rumen by removing $\mathrm{H}_{2}$ that benefits the donors by providing an electron sink for reducing equivalents to minimize the partial pressure of $\mathrm{H}_{2}$ in the rumen (Wolin et al., 1997; Russell, 2002). Methanogens are found in a symbiotic relationship with ruminal bacteria (Wolin et al., 1997) and protozoa (Lange et al., 2005). Only a few species of methanogens have been successfully isolated from the rumen and identified because of their stringent requirements for growth. Recent studies using molecularbased approaches have reported that the differences in methanogenic profiles, not the total population of methanogens may be associated with feed efficiency of cattle (Zhou et al., 2009 and 2010). The methanogenic community in +RFI cattle has been observed to be more diverse than that in -RFI cattle, and the differences at genus, species, strain and genotype levels were associated with feed efficiency when fed low energy diets. Several researchers have examined the relationship between methanogenic populations and variation in feed efficiency. The observed proportion of Methanosphaera stadtmanae and Methanobrevibacter sp. $\mathrm{AbM} 4$ in the rumen were higher in + RFI compared with - RFI cattle (Zhou et al., 2009). M. stadtmanae utilizes methanol for $\mathrm{CH}_{4}$ synthesis (Miller and Wollin, 1985), and M. sp. AbM4 is closely related to Methanobrevibacter smithii, a species that utilizes acetate for $\mathrm{CH}_{4}$ production (Zhou et al., 2009). These results suggest increases in populations that shift more organic substrates to $\mathrm{CH}_{4}$ biosynthesis pathways, which may contribute to low feed efficiency. In addition, the association between methanogen profiles and RFI was affected when the animals were switched from low to high-energy diets (Zhou et al., 2010). These results suggest that the diversity of the methanogenic community affects $\mathrm{CH}_{4}$ emissions and feed efficiency in cattle. However, $\mathrm{CH}_{4}$ was not measured in the above studies, and trials to link the methanogenic profiles with the $\mathrm{CH}_{4}$ emissions are necessary to verify and elucidate the roles of methanogen in the animals with different feed efficiency. Furthermore, the interaction between methanogens and bacteria, as well as protozoa is largely unknown.

\section{Breeding for low $\mathrm{RFI}$ and reduced $\mathrm{CH}_{4}$ emissions}

Actual selection for RFI has been conducted at the Trangie Agricultural Research Centre, NSW, Australia, with a direct yearly response because of selection of $-0.125 \mathrm{~kg} D M /$ day compared with no selection for RFI (Arthur et al., 2001c). However, given that multi-trait breeding goals will be pursued by the industry, Alford et al. (2006) assumed an annual rate of response in RFI of $-0.08 \mathrm{~kg} \mathrm{DM} /$ day $(0.8 \% / y e a r)$ in a 25-year simulation assessing the impact on enteric $\mathrm{CH}_{4}$ abatement for the Australian beef industry. Cumulative $\mathrm{CH}_{4}$ reduction over 25 years was $568100 t$ which was equivalent to an annual reduction of $568100 \mathrm{t} \mathrm{CO}_{2} \mathrm{e} / \mathrm{year}$ or $\$ 8.5$ million/year in carbon credits assuming a global warming potential of 25 for $\mathrm{CH}_{4}$ and a value of $\$ 15 / t$ for $\mathrm{CO}_{2} \mathrm{e}$. This study did not account for reduced manure $\mathrm{CH}_{4}$ and $\mathrm{N}_{2} \mathrm{O}$, cropping $\mathrm{N}_{2} \mathrm{O}$ and energy $\mathrm{CO}_{2}$ because of reduced feed requirements resulting from lower RFI. The HOLOS wholefarm model (Little et al., 2008) which does account for enteric $\mathrm{CH}_{4}$, manure $\mathrm{CH}_{4}$ and $\mathrm{N}_{2} \mathrm{O}$, cropping $\mathrm{N}_{2} \mathrm{O}$ and energy $\mathrm{CO}_{2}$ was used to predict the reduction in total GHG emissions that would occur after 25 years of selection for - RFI compared with a baseline 120-cow herd ( four breeding bulls) not selected for RFI. Animal and cropping data from Beauchemin et al. (2010), percentage RFI reduction (\% of base year) for different age cohorts in a commercial herd over 25 years from Alford et al. (2006), and updated global warming potentials of 25 for $\mathrm{CH}_{4}$ and 298 for $\mathrm{N}_{2} \mathrm{O}$ were used for this HOLOS simulation. After 25 years of selection for - RFI, the efficient 120-cow beef herd had lower GHG emissions by $101 \mathrm{t} \mathrm{CO}_{2} \mathrm{e}$ per year or $0.844 \mathrm{t} \mathrm{CO}_{2} \mathrm{e}$ per cow per year compared with the average 120-cow herd. In addition, the feed nitrogen use efficiency and carbon footprint of the 
efficient herd were improved by $17 \%$ to $22 \%$ and $14 \%$, respectively, compared with the cow herd not selected for RFI (19.82 v. $23.06 \mathrm{~kg} \mathrm{CO}_{2} \mathrm{e} / \mathrm{kg}$ carcass beef) and the total farm area decreased by $13 \%$ because we use less farm grown resources to produce an equivalent amount of animal product. These estimates of GHG reduction are conservative as improved DM digestibility in -RFI cattle and improved accuracy and rate of genetic change resulting from genomic enhanced breeding values were not considered.

There is on-going debate as to the best methods to use when selecting for improved RFI. The merit of including RFI in the breeding goal over and above just feed intake exists to a different extent depending on the breeding tools available to a particular group of producers. For example, where a multiple trait selection index is used, including RFI as a goal trait may hold little or no advantage to using the components (feed intake, ADG, metabolic LW and back fat) as goal traits along with proper weightings. However, RFI may be a 'cleaner' trait than feed intake to include as it is essentially feed intake corrected for different energy uses at the time of measurement. Similarly, since RFI is effectively a selection index, a feed efficiency sub-index can be derived using restricted selection index methodology (Eisen, 1977). Ultimately, including either feed intake or RFI in a breeding goal is mathematically equivalent given that all parameters are known without error (Van der Werf, 2004).

In a situation where only expected progeny difference (EPD) are generated for different traits, and selection pressure for each trait is determined by the producer, selecting for multiple traits simultaneously as well as attempting to select for feed efficiency without a direct measure may be a lot to ask. Selecting for reduced feed intake alone may be equivalent as producers would inherently select for increased weaning weight but the notion of selecting for reduced feed intake (if selection pressure was left to the producer) may seem improper especially when there is a 'feed for fertility' mantra in existence. In this instance, deriving EPD for RFI is useful. In a third situation, where no genetic evaluation is available to the producer, RFI can be used to rank animals for feed efficiency within population. It should also be taken into consideration when proposing $\mathrm{RFI}, \mathrm{RIG}$ or residual intake and gain to producers as a selection criterion that it is a difficult concept to grasp (Wulfhorst et al., 2010) and this may lower industry acceptance of residual feed efficiency measures. It is positive to note that $\mathrm{RFI}$ is favorably genetically correlated or not correlated with the majority of other production and carcass quality traits as previously discussed and selection for RFI will reduce GHG emissions in ruminants.

\section{Conclusion}

Selection for feed efficiency through residual or its component traits (DMI, BW, ADG and backfat) in a multi-trait selection index will result in slow incremental improvement to feed efficiency and methane intensity, with few antagonistic effects on traits of economic importance.

\section{Acknowledgements}

This paper was published as part of a supplement to animal, publication of which was supported by the Greenhouse Gases \& Animal Agriculture Conference 2013. The papers included in this supplement were invited by the Guest Editors and have undergone the standard journal formal review process. They may be cited. The Guest Editors appointed to this supplement are R. J. Dewhurst, D. R. Chadwick, E. Charmley, N. M. Holden, D. A. Kenny, G. Lanigan, D. Moran, C. J. Newbold, P. O'Kiely, and T. Yan. The Guest Editors declare no conflict of interest.

\section{References}

Abberton MT, MacDuff JH, Athole HM and Humphreys MW 2007. The genetic improvement of forage grasses and legumes to reduce greenhouse gas emissions. Communication Division, FAO, Viale delle Terme di Caracalla 00153 Rome, Italy, 15pp.

Alford AR, Hegarty RS, Parnell PF, Cacho OJ, Herd RM and Griffith GR 2006. The impact of breeding to reduce residual feed intake on enteric methane emissions from the Australian beef industry. Australian Journal of Experimental Agriculture $46,813-820$.

Allen VG, Fontenot JP, Notter DR and Hammes RC Jr 1992. Forage systems for beef production from conception to slaughter: I cow-calf production. Journal of Animal Science 70, 576-587.

Archer JA, Reverter A, Herd RM, Johnston DJ and Arthur PF 2002. Genetic variation in feed intake and efficiency of mature beef cows and relationships with postweaning measurements. Proceedings of the 7th World Congress on Genetics Applied to Livestock Production, 31, pp. 221-224.

Archer JA, Richardson EC, Herd RM and Arthur PF 1999. Potential for selection to improve efficiency of feed use in beef cattle: a review. Australian Journal of Agricultural Research 50, 147-161.

ARD 2005. Alberta agriculture and rural development. economic, productive and financial benchmarks for Alberta cow/calf operations. Retrieved November 20, 2012, from http://www1.agric.gov.ab.ca/\$department/deptdocs.nsf/ all/econ8479

Arthur PF, Herd RM, Wilkins JF and Archer JA 2005. Maternal productivity of Angus cows divergently selected for post-weaning residual feed intake. Australian Journal of Experimental Agriculture 45, 985-993.

Arthur PF, Renand G and Krauss D 2001a. Genetic and phenotypic relationships among different measures of growth and feed efficiency in young Charolais bulls. Livestock Production Science 68, 131-139.

Arthur PF, Archer JA, Johnson DJ, Herd RM, Richardson EC and Parnell PF 2001b. Genetic and phenotypic variance and covariance components for feed intake, feed efficiency and other postweaning traits in Angus cattle. Journal of Animal Science 79, 2805-2811.

Arthur PF, Archer JA, Herd RM and Melville GJ 2001c. Response to selection for net feed intake in beef cattle. Proceedings of the Association for the Advancement in Animal Breeding and Genetics 13, 135-138.

Basarab J, Baron V, López-Campos Ó, Aalhus J, Haugen-Kozyra K and Okine E 2012a. Greenhouse gas emissions from calf- and yearling-fed beef production systems, with and without the use of growth promotants. Animals 2, 195-220. Basarab JA, Fitzsimmons C, Whisnant CS and Wettemenn RP 2012b. Interactions with other traits: reproduction and fertility. In Feed Efficiency in the Beef Industry (ed. RA Hill), pp. 123-144. Wiley-Blackwell, Ames, lowa, USA. Basarab JA, McCartney D, Okine EK and Baron VS 2007. Relationships between progeny residual feed intake and dam productivity traits. Canadian Journal of Animal Science 87, 489-502.

Basarab JA, Price MA, Aalhus JL, Okine EK, Snelling WM and Lyle KL 2003. Residual feed intake and body composition in young growing cattle. Canadian Journal of Animal Science 83, 189-204.

Basarab JA, Colazo MG, Ambrose DJ, Novak S, McCartney D and Baron VS 2011. Residual feed intake adjusted for backfat thickness and feeding frequency is independent of fertility in beef heifers. Canadian Journal of Animal Science 91, 573-584.

Beauchemin KA and McGinn SM 2005. Methane emissions from feedlot cattle fed barley or corn diets. Journal of Animal Science 83, 653-661. 
Beauchemin KA and McGinn SM 2006. Enteric methane emissions from growing beef cattle as affected by diet and level of intake. Canadian Journal of Animal Science 86, 401-408.

Beauchemin KA, McAllister TA and McGinn SM 2009. Dietary mitigation of enteric methane from cattle. $C A B$ Reviews: Perspectives in Agriculture, Veterinary Science, Nutrition and Natural Resources 4, No. 035.

Beauchemin KA, Kreuzer M, O'Mara F and McAllister TA 2008. Nutritional management for enteric methane abatement: a review. Australian Journal of Experimental Agriculture 48, 21-27.

Beauchemin KA, Janzen H, Little SM, McAllister TA and McGinn SM 2010. Life cycle assessment of greenhouse gas emissions from beef production in western Canada: a case study. Agricultural Systems 103, 371-379.

Berry DP 2012. Breeding strategies to reduce environmental footprint in dairy cattle animal and grassland research and innovation centre. Teagasc, Moorepark, Fermoy, Co., Cork, Ireland.

Berry DP and Crowley JJ 2012. Residual intake and body weight gain: a new measure of efficiency in growing cattle. Journal of Animal Science 90, 109-115.

Bingham GM, Friend TH, Lancaster PA and Carstens GE 2009. Relationship between feeding behavior and residual feed intake in growing Brangus heifers. Journal of Animal Science 87, 2685-2689.

Bishop MD, Davis ME, Harvey WR, Wilson GR and VanStavern BD 1991 Divergent selection for postweaning feed conversion in Angus beef cattle: II. Genetic and phenotypic correlations and realised heritability estimates. Journal of Animal Science 69, 4360-4367.

Blaxter KL and Clapperton JL 1965. Prediction of the amount of methane produced by ruminants. British Journal of Nutrition 19, 511-522.

Brulc JM, Antonopoulos DA, Miller ME, Wilson MK, Yannarell AC, Dinsdale EA, Edwards RE, Frank ED, Emerson JB, Wacklin P, Coutinho PM, Henrissat B, Nelson $\mathrm{KE}$ and White BA 2009. Gene-centric metagenomics of the fiber-adherent bovine rumen microbiome reveals forage specific glycoside hydrolases. Proceedings of the National Academy of Science USA 106, 1948-1953.

Capper JL 2011. The environmental impact of beef production in the United States: 1977 compared with 2007. Journal of Animal Science 89, 4249-4261.

Carberry CA, Kenny DA, Han S, McCabe MS and Waters SM 2012. Effect of phenotypic residual feed intake and dietary forage content on the rumen microbial community of beef cattle. Applied Environmental Microbiology 78 , 4949-4958.

Carstens GE and Tedeschi LO 2006. Defining feed efficiency in beef cattle. Proceedings of the Beef Improvement Federation 38th Annual Research Symposium and Annual Meeting, April 18-21, Choctow, MS, USA, 12-21pp.

Cederberg C, Persson M, Neovius K, Molander S and Clift R 2011. Including carbon emissions from deforestation in the carbon footprint of Brazilian beef. Environmental Science and Technology 45, 1773-1779.

Clark H, Kelliher F and Pinares-Patiño C 2011. Reducing $\mathrm{CH}_{4}$ emissions from grazing ruminants in New Zealand: challenges and opportunities. AsianAustralian Journal of Animal Science 24, 295-302.

Cotta MA 1992. Interaction of ruminal bacteria in the production and utilization of maltoologosaccrides from starch. Applied Environmental Microbiology 58, 48-54.

Crews DH Jr 2005. Genetics of efficient feed utilization and national cattle evaluation: a review. Genetics and Molecular Research 4, 152-165.

Crews DH Jr, Shannon NH, Genswein BMA, Crews RE, Johnson CM and Kendrick BA 2003. Genetic parameters for net feed efficiency of beef cattle measured during postweaning growing versus finishing periods. Proceedings, Western Section, American Society of Animal Science 54, 1-4.

Crowley JJ, McGee M, Kenny DA, Crews DH Jr, Evans RD and Berry DP 2010. Phenotypic and genetic parameters for different measures of feed efficiency in different breeds of Irish performance-tested beef bulls 2010. Journal of Animal Science 88, 885-894

Crowley JJ, Evans RD, Mc Hugh N, Pabiou T, Kenny DA, McGee M, Crews DH Jr and Berry DP 2011. Genetic associations between feed efficiency measured in a performance test station and performance of growing cattle in commercial beef herds. Journal of Animal Science 89, 3382-3393.

Cruz GD, Rodriguez-Sanchez JA, Oltjen JW and Sainz RD 2010. Performance, residual feed intake, digestibility, carcass traits, and profitability of Angus-Hereford steers housed in individual or group pens. Journal of Animal Science 88, 324-329.

De Haas Y, Windig JJ, Calus MPL, Dijkstra J, de Haan M, Bannink A and Veerkamp RF 2011. Genetic parameters for predicted methane production and potential for reducing enteric emissions through genomic selection. Journal of Dairy Science 94, 6122-6134.

Dewhurst RJ, Delaby L, Moloney A, Boland T and Lewis E 2009. Nutritive value of forage legumes used for forage and grazing. Irish Journal of Agricultural and Food Research 48, 167-187.

Durunna ON, Mujibi FDN, Goonewardene L, Okine EK, Basarab JA, Wang Z and Moore SS 2011. Feed efficiency differences and re-ranking exist in beef steers fed grower and finisher diets. Journal of Animal Science 89, 158-167.

Eisen EJ 1977. Restricted selection index: an approach to selecting for feed efficiency. Journal of Animal Science 44, 958-972.

Eschenlauer SCP, McKain N, Walker ND, McEwan NR, Newbold CJ and Wallace RJ 2002. Ammonia production by ruminal microorganisms and enumeration, isolation, and characterization of bacteria capable of growth on peptides and amino acids from the sheep rumen. Applied Environmental Microbiology 68, 4925-4931.

FAO 2009. How to feed the world in 2050. FAO, Rome, Italy.

Ferrell CL and Jenkins TG 1985. Cow type and nutritional environment: nutritional aspects. Journal of Animal Science 61, 725-741.

Ghoshal B, Hernandez-Sanabria E, Zhou M, Stothard P and Guan LL 2012. Domesticated bovinae (cattle): terrestrial vertebrate metagenomics. In Encyclopedia of metagenomics (ed. KE Nelson, BA White, S Highlander and F Rodriguez-Valera). Springer.

Golden JW, Kerley MS and Kolath WH 2008. The relationship of feeding behaviour to residual feed intake in crossbred Angus steers fed traditional and no-roughage diets. Journal of Animal Science 86, 180-186.

Gomes RD, Sainz RD and Leme PR 2013. Protein metabolism, feed energy partitioning, behavior patterns and plasma cortisol in Nellore steers with high and low residual feed intake. Revista Brasileira de Zootecnia 42, 44-50.

Grainger C, Clarke T, McGinn SM, Auldist MJ, Beauchemin KA, Hannah MC, Waghorn GC, Clark H and Eckard RJ 2007. Methane emissions from dairy cows measured using the sulfur hexafluoride (SF6) tracer and chamber techniques. Journal of Dairy Science 90, 2755-2766.

Guan LL, Nkrumah DJ, Basarab JA and Moore SS 2008. Linkage of microbial ecology to phenotype: correlation of rumen microbial ecology to cattle's feed efficiency. FEMS Microbiology Letters 288, 85-91.

Gunsett FC 1984. Linear index selection to improve traits defined as ratios. Journal of Animal Science 59, 1185-1193.

Hafla AN, Lancaster PA, Carstens GE, Forrest DW, Fox JT, Forbes TDA, Davis ME, Randel RD and Holloway JW 2012. Relationships between feed efficiency, scrotal circumference, and semen quality traits in yearling bulls. Journal of Animal Science 90, 3937-3944.

Harper LA, Denmead OT, Freney JR and Byers FM 1999. Direct measurements of methane emissions from grazing and feedlot cattle. Journal of Animal Science 77, 1392-1401.

Hegarty RS, Goopy JP, Herd RM and McCorkell B 2007. Cattle selected for lower residual feed intake have reduced daily methane production. Journal of Animal Science 85, 1479-1486.

Herd RM and Arthur PF 2009. Physiological basis for residual feed intake. Journal of Animal Science 87 (E. Suppl.), E64-E71.

Herd RM and Bishop SC 2000. Genetic variation in residual feed intake and its association with other production traits in British Hereford cattle. Livestock Production Science 63, 111-119.

Herd RM, Oddy VH and Richardson EC 2004. Biological basis for variation in residual feed intake in beef cattle. 1. Review of potential mechanisms. Australian Journal of Experimental Agriculture 44, 423-430.

Herd RM, Arthur PF, Hegarty RS and Archer JA 2002. Potential to reduce greenhouse gas emissions from beef production by selection for reduced residual feed intake. Proceedings of the 7th world congress on genetics applied to livestock production, Montpellier, France. Comm. no. 10-22.

Hernandez-Sanabria E, Guan LL, Goonewardene LA, Li M, Fujibi D, Stothard P, Moore SS and Leon-Quintero MC 2010. Association between microbial diversity and microbial fermentation parameters in the bovine rumen and host's feed efficiency traits. Applied Environmental Microbiology 76, 6338-6350.

Hill A and Ahola JK 2012. Feed efficiency interactions with other traits: growth and product quality. InFeed efficiency in the beef industry (ed. RA Hill), pp. 145-158. Wiley-Blackwell, Ames, lowa, USA.

IPCC 2006. Revised guidelines for national greenhouse gas inventories. IPCC/ OECD/IEA/IGES. Vol. 4. Agriculture, forestry and other land use. Chapter 11. 
$\mathrm{N}_{2} \mathrm{O}$ emissions from managed soils and $\mathrm{CO}_{2}$ emissions from lime and urea application. Retrieved November 20, 2012, from http://www.ipcc-nggip.iges.or.jp/ public/2006gl/pdf/4-Volume_4/V4._11-Ch11_N2O\&CO2pdfhtm

Imachi H, Sekiguchi Y, Kamagata Y, Hanada S, Ohashi A and Harada H 2002. Pelotomaculum thermopropionicum gen. nov., sp. nov., an anaerobic, thermophilic, syntrophic propionate-oxidizing bacterium. International Journal of Systematic and Evolutionary Mircobiology 52, 1729-1735.

Johnson KA and Johnson DE 1995. Methane emissions from cattle. Journal of Animal Science 73, 2483-2492.

Johnson K, Huyler M, Westberg H, Lamb B and Zimmerman P 1994. Measurement of methane emissions from ruminant livestock using FS6 tracer technique. Environmental Science and Technology 28, 359-362.

Jones FM, Phillips FA, Naylor T and Mercer NB 2011. Methane emissions from grazing Angus beef cows selected for divergent residual feed intake. Animal Feed Science and Technology 166-167, 302-307.

Kelly AK, McGee M, Crews DH Jr, Fahey AG, Wylie AR and Kenny DA 2010a. Effect of divergence in residual feed intake on feeding behavior, blood metabolic variables, and body composition traits in growing heifers. Journal of Animal Science 88, 109-123.

Kelly AK, McGee M, Crews DH Jr, Sweeney T, Boland TM and Kenny DA 2010b. Repeatability of feed efficiency, carcass ultrasound, feeding behavior, and blood metabolic variables in finishing heifers divergently selected for residual feed intake. Journal of Animal Science 88, 3214-3225.

Kennedy BW, Van der Werf JHJ and Meuwissen THE 1993. Statistical and genetic properties of residual feed intake. Journal of Animal Science 71, 3239-3250.

Koch RM, Swiger LA, Chambers D and Gregory KE 1963. Efficiency of feed use in beef cattle. Journal of Animal Science 22, 486-494.

Koots KR, Gibson JP, Smith C and Wilton JW 1999. Analyses of published genetic parameter estimates for beef production traits. 2. Phenotypic and genetic correlations. Animal Breeding Abstracts 62, 309-338.

Lange M, Westermann $P$ and Ahring BK 2005. Archaea in protozoa and metazoa. Applied Microbiology and Biotechnology 66, 465-474.

Lawrence P, Kenny DA, Earley B, Crews DH Jr and McGee M 2011. Grass silage intake, rumen and blood variables, ultrasonic and body measurements, feeding behavior and activity in pregnant beef heifers differing in phenotypic residual feed intake. Journal of Animal Science 89, 3248-3261.

Little S, Linderman J, Maclean K and Janzen H 2008. HOLOS-a tool to estimate and reduce greenhouse gases from farms. Methodology and algorithms for versions 1.1x, Agriculture and Agri-Food Canada, Cat. no. A52-136/2008E-PDF, 158pp. Lovett DK, Stack LJ, Lovell S, Callan J, Flynn B, Hawkins M and O'Mara FP 2005. Manipulating enteric methane emissions and animal performance of late lactation dairy cows through concentrate supplementation at pasture. Journal of Dairy Science 88, 2836-2842.

McAllister TA and Newbold CJ 2008. Redirecting rumen fermentation to reduce methanogenesis. Australian Journal of Experimental Agriculture 48, 7-13.

McGee M 2009. What feed efficiency in the suckler cow has to offer beef farmers. Irish Grassland Association Journal 43, 125-131.

Montanholi YR, Swanson KC, Vander Voort G, Smith B, Haas LS and Miller SP 2011. Assessment of heat and methane production in beef cattle with different feed efficiency. Proceedings of the $60^{\text {th }}$ Annual Meeting of the Canadian Animal Science Society, Halifax, Canada, 36pp.

Montanholi YR, Swanson KC, Palme R, Schenkel FS, McBride BW, Lu D and Miller SP 2010. Assessing feed efficiency in beef steers through feeding behaviour, infrared thermography and glucocorticoids. Animal 4, 692-701.

Montano-Bermudez M, Nielson MK and Deutscher GH 1990. Energy requirements for maintenance of crossbred beef cattle with different genetic potential for milk. Journal of Animal Science 68, 2279-2288.

Nkrumah DJ, Crews DH Jr, Basarab JA, Price MA, Okine EK, Wang Z, Li C and Moore SS 2007. Genetic and phenotypic relationships of feeding behavior and temperament with performance, feed efficiency, ultrasound, and carcass merit of beef cattle. Journal of Animal Science 85, 2382-2390.

Nkrumah DJ, Okine EK, Mathison GW, Schnid K, Li C, Basarab JA, Price MA, Wang Z and Moore SS 2006. Relationships of feedlot feed efficiency, performance, and feeding behavior with metabolic rate, methane production, and energy partitioning in beef cattle. Journal of Animal Science 84, 145-153. Nkrumah JD, Basarab JA, Price MA, Okine EK, Ammoura A, Guercio S, Hansen C, Li C, Benkel B, Murdoch B and Moore SS 2004. Different measures of energetic efficiency and their phenotypic relationships with growth, feed intake, and ultrasound and carcass merit in hybrid cattle. Journal of Animal Science 82, 2452-2459.

NRC 2000. Nutrient requirements of beef cattle, 7th edition. National Academy Press, Washington, DC, USA.

Ørskov ER, Fraser C, Mason VC and Mann SO 1988. A study on consistency of differences between cows in rumen outflow rate of fibrous particles and other substrates and consequences for digestibility and intake of roughages. Animal Production 47, 45-51.

Pinares-Patinõ CS, Baumont R and Martin C 2003. Methane emissions by Charolais cows grazing a monospecific pasture of timothy at four stages of maturity. Canadian Journal of Animal Science 83, 769-777.

Pinares-Patinõ CS, McEwan JC, Dodds KG, Cárdenas EA, Hegarty RS, Koolaard JP and Clark H 2011. Repeatability of methane emissions from sheep. Animal Feed Science and Technology 166-167, 210-218.

Ramsey R, Doye D, Ward C, McGrann J, Falconer L and Bevers S 2005. Factors affecting beef cow-herd costs, production, and profits. Journal of Agricultural and Applied Economics 37, 91-99.

Rauw WM 2012. Feed efficiency and animal robustness. In Feed efficiency in the beef industry (ed. RA Hill), pp. 105-122. Wiley-Blackwell, Ames, lowa, USA.

Richardson EC, Herd RM, Oddy VH, Thompson JM, Archer JA and Arthur PF 2001. Body composition and implications for heat production of Angus steer progeny of parents selected for and against residual feed intake. Australian Journal of Experimental Agriculture 41, 1065-1072.

Rius AG, Kittelmann S, Macdonald KA, Waghorn GC, Janssen PH and Sikkema ER 2012. Nitrogen metabolism and rumen microbial enumeration in lactating cows with divergent residual feed intake fed high-digestibility pasture. Journal of Dairy Science 95, 5024-5034.

Robinson DL and Oddy VH 2004. Genetic parameters for feed efficiency, fatness, muscle area and feeding behaviour of feedlot finished beef cattle. Livestock Production Science 90, 255-270.

Robinson DL, Oddy VH, Dicker RW and McPhee MJ 2001. Post-weaning growth of cattle in northern New South Wales. 3. Carry-over effects on finishing, carcass characteristics and intramuscular fat. Australian Journal of Experimental Agriculture 41, 1041-1049.

Robinson DL, Goopy JP, Hegarty RS and Vercoe PE 2010. Repeatability, animal and sire variation in 1-hr methane emissions and relationships with rumen volatile fatty acid concentrations. In Proceedings of the $9^{\text {th }}$ World Congress on Genetics Applied to Livestock production (ed. Gesellschaft für Tierzuchtwissenschaften e. V), p. 0712. German Society for Animal Science. Retrieved May 5 , 2013, from http://www.kongressband.de/wcgalp2010/assets/pdf/0712.pdf

Russell JB 2002. Predominant ruminal bacteria and archaea. In Rumen microbiology and its role in ruminant nutrition (ed. JB Russell), pp. 19. JB Russell Publishing Company, Ithaca, NY, USA.

Russell RW and Gahr SA 2000. Glucose availability and associated metabolism. In Farm animal metabolism and nutrition (ed. JPF D'Mello), pp. 121-147. Centre for Agricultural Bioscience International Publishing, Wallingford, UK.

Schenkel FS, Miller SP and Wilton JW 2004. Genetic parameters and breed differences for feed efficiency, growth and body composition traits of young beef bulls. Canadian Journal Animal Science 84, 177-185.

Shaffer KS, Turk P, Wagner WR and Felton EED 2011. Residual feed intake, body composition, and fertility in yearling beef heifers. Journal of Animal Science 89, 1028-1034.

Stevenson DM and Weimer PJ 2007. Dominance of Prevotella and low abundance of classical ruminal bacterial species in the bovine rumen revealed by relative quantification real-time PCR. Applied Microbiology and Biotechnology 75, 165-174. Stewart CS, Flint HJ and Bryant MP 1997. The rumen bacteria. In The rumen microbial system, 2nd edition (ed. PN Hobson and CS Stewart), pp. 10-72. Blackie Academic and Professional, New York, NY, USA.

Van der Werf JHJ 2004. It is useful to define residual feed intake as a trait in animal breeding programs? Australian Journal of Experimental Agriculture 44, 405-410.

Verge XPC, Dyer JA, Desjardins RL and Worth D 2008. Greenhouse gas emissions from the Canadian beef industry. Agricultural Systems 98, 126-134. Waghorn GC and Hegarty RS 2011. Lowering ruminant methane emissions through improved feed conversion efficiency. Animal Feed Science and Technology 166-167, 291-301.

Wallace RJ, McKain N and Broderick GA 1993. Breakdown of different peptides by Prevotella (Bacteroides) ruminicola and mixed microorganisms from the sheep rumen. Current Microbiology 26, 333-336. 


\section{Reducing methane through improved feed efficiency}

Wang Z, Nkrumah DJ, Li C, Basarab JA, Goonewardene LA, Okine EK, Crews DH J and Moore SS 2006. Test duration for growth, feed intake, and feed efficiency in beef cattle using the GrowSafe System. Journal of Animal Science 84, 2289-2298.

Wang Z, Colazo MG, Basarab JA, Goonewardene LA, Ambrose DJ, Marques E, Plastow G, Miller SP and Moore SS 2012. Impact of selection for residual feed intake on breeding soundness and reproductive performance of bulls on pasture-based multisire mating. Journal of Animal Science 90, 2963-2969.

Wolin MJ, Miller TL and Stewart CS 1997. Microbe-microbe interactions. In The rumen microbial ecosystem, 2nd edition (ed. PM Hobson and CW Stewart), pp. 467-491. Blackie Academic and Professional, London, England, UK.
Wulfhorst JD, Ahola JK, Kane SL, Keenan LD and Hill RA 2010. Factors affecting beef cattle producer perspectives on feed efficiency. Journal of Animal Science 88, 3749-3758.

Zhou M, Hernandez-Sanabria E and Guan LL 2009. Assessment of microbial ecology of ruminal methane producers and cattle's high feed efficiency and low methane production activities. Applied Environmental Microbiology 75, 6524-6533.

Zhou M, Hernandez-Sanabria E and Guan LL 2010. Characterization of rumen methanogenic community variation under different diets and host feed efficiencies using PCR-DGGE analysis. Applied Environmental Microbiology 76, 3776-3786. 